\title{
Pembenahan taman pkk
}

Muh iqra saleh

Nim: 9173770410242

Email: muh444416@gmail.com

1. Bentuk kegiatan

Pembenahan taman pkk

2. Lokasi

Kantor kelurahan tolo kota

3. Hari/tanggal dan waktu senin, 28 september s/d 5 oktober 2020

Waktu 08:00 WIB sampai selesai.

4. Peserta yang dilibatkan Mahasiswa

5. Alasan diadakannya Agar taman pkk lebih rapi, indah dan menarik dilihat.

6. Tujuan dan manfaat Agar tanaman obat atau tumbuhan yang ditaman bisa dimanfaatkan, baik dari tanaman sayur ataupun tanaman obat,dan berbagai tanaman bunga dapat mengindahkan pandangan dan suasana menjadi sejuk.

7. Deskripsi kegiatan

Pertama kami membuat pot bunga yang terbuat dari botol bekas setelah itu kami mengecetnya dengan warna yang menarik setelah selesai kami membuatnya, kami membawa po bunga tersebut ke taman pkk untuk dijadikan pot bunga setelah itu kami menyusun atau merapikan pot bunga agar terlihat rapi dan indah dilihat. . 